\title{
APLIKASI METODE FUZZY C-MEANS UNTUK PENGKLASTERAN KELAYAKAN RUMAH DI DESA WAYAME, AMBON
}

\author{
R. P. A. Sormin 1 , F. Y. Rumlawang ${ }^{2}$, L. J. Sinay ${ }^{3}$ \\ 1, 2, 3 Jurusan Matematika FMIPA Universitas Pattimura \\ Jl. Ir. M. Putuhena, Kampus Unpatti, Poka-Ambon, Indonesia \\ e-mail: ${ }^{3}$ lj.sinay@ staff.unpatti.ac.id
}

\begin{abstract}
Abstrak
Pengklasteran adalah proses pengelompokan data ke dalam klaster berdasarkan parameter tertentu sehingga obyek-obyek dalam sebuah klaster memiliki tingkat kemiripan yang tinggi satu sama lain dan sangat tidak mirip dengan obyek yang lain pada klaster yang berbeda. Algoritma Fuzzy C-Means termasuk salah satu teknik pengklasteran data yang mana keberadaan pada setiap titik data dalam suatu klaster ditentukan oleh derajat keanggotaan. Pada penelitian ini Algoritma Fuzzy C-Means digunakan untuk menentukan kelayakan rumah. Hasil yang diperoleh menunjukkan bahwa masih banyak rumah yang tidak layak di Desa wayame yang harus lebih diperhatikan.
\end{abstract}

Kata Kunci: C-Means, fuzzy, kelayakan, pengklasteran.

\section{APLICATION OF FUZZY C-MEANS ALGORITHM FOR CLUSTERING HOUSE FEASIBILITY IN WAYAME VILLAGE, AMBON}

\begin{abstract}
Clustering is a process of organizing objects into groups whose members are similar in a cluster but different with members of other cluster. Fuzzy C-Means Algorithm is a data clustering technique in which a dataset is grouped into clusters with every data point in the data sets belonging to every cluster to a certain degree. In this research Fuzzy C-Means Algorithm is used to determine house feasibility. The result shows that there are many houses which are not feasible and need to get more attention.
\end{abstract}

Keywords: C-means, clustering, fuzzy, feasibility.

\section{Pendahuluan}

Secara garis besar kelayakan merupakan tahap dimana pantas atau tidaknya sesuatu berada pada tempat tertentu. Penentuan kelayakan merupakan hal yang sangat penting dilakukan dalam mempertimbangkan dan mengambil sebuah keputusan. Masalah penentuan kelayakan seringkali menjadi masalah yang sangat rumit dan kompleks, sehingga membutuhkan solusi yang sangat tepat dan sesuai. Sehingga output yang dihasilkan sesuai dengan yang diharapkan.

Penentuan kelayakan bisa terjadi dalam berbagai kasus, salah satunya adalah penentuan kelayakan kelayakan rumah hunian. Menurut Peraturan Menteri Negara Perumahan Rakyat Republik Indonesia nomor: 22/Permen/M/2008 tentang standar pelayanan minimal bidang perumahan rakyat daerah provinsi dan daerah kabupaten/kota menyatakan bahwa rumah layak huni adalah rumah yang memenuhi persyaratan keselamatan bangunan dan kecukupan minimum luas bangunan serta keselamatan penghuninya.

Beberapa kriteria sudah ditentukan untuk melihat rumah yang layak huni, sehingga diperlukan pengujian untuk mengetahui yang layak dan mana yang tidak layak untuk dihuni oleh masyarakat. Metode pengklasteran dengan algorithma Fuzzy C-Means akan digunakan untuk menentukan kelayakan rumah tersebut. 
Pada penelitian ini, kelayakan rumah masyarakat di Desa Wayame ditentukan menggunakan Metode pengklasteran dengan algoritma Fuzzy C-Means berdasarkan kriteria-kriteria yang telah ditentukan. Dengan demikian, tujuan dari penelitian ini adalah untuk menentukan kelayakan rumah masyarakat di Desa Wayame menggunakan Metode Pengklasteran dengan algorithma Fuzzy C-Means berdasarkan kriteria-kriteria yang telah ditentukan.

\section{Tinjauan Pustaka}

Fuzzy C-Means (FCM) adalah suatu teknik pengklasteran data yang mana keberadaan tiap-tiap titik data dalam suatu klaster ditentukan oleh derajat keanggotaan. Teknik ini pertama kali diperkenalkan oleh Jim Bezdek pada tahun 1981. Fuzzy C-Means memungkinkan pengelompokkan dimana kelompok data tidak terdistribusi secara jelas [1].

Pengelompokkan data dengan metode ini sebelumnya sudah dibuat dan digunakan, namun dengan aplikasi yang berbeda bahkan menggunakan program yang dapat mempermudah. Beberapa yang pernah dibuat adalah:

Metode Klastering dengan Algoritma Fuzzy C-Means untuk Rekomendasi pemilihan bidang keahlian pada program studi teknik informatika [2]. Dalam penelitian ini Algoritma Fuzzy C-Means untuk rekomendasi penjurusan dapat diterapkan dengan manfaat penentu mahasiswa masuk kelompok mana dan setiap kelompok diidentifikasikan sebagai jurusan apa.

Kemudian Analisis Penyandang Masalah Kesejahteraan Sosial di Indonesia Menggunakan Metode Fuzzy C-Means Klastering dan Biplot [3]. Dalam penelitian ini Fuzzy C-Means pengklasteran digunakan untuk mengelompokkan data ke dalam klaster tertentu sedangkan biplot untuk memberikan penerangan ke dalam plot.

\subsection{Definisi Pengklasteran}

Pengklasteran adalah suatu metode pengelompokan berdasarkan ukuran kedekatan (kemiripan). Pengklasteran membagi data menjadi kelompok-kelompok atau klasters berdasarkan suatu kemiripan atributatribut diantara data tersebut. Karakteristik tiap klaster tidak ditentukan sebelumnya, melainkan tercermin dari kemiripan data yang terkelompok di dalamnya. Beberapa teknik pengklasteran dalam data mining meliputi: skalabilitas, kemampuan untuk menangani tipe atribut yang berbeda, menangani data yang mengandung noise, mampu menangani dimensionalitas yang tinggi, dan dapat diterjemahkan dengan mudah. Pengklasteran beda dengan grup, kalau grup berarti kelompok yang sama, kondisinya kalau tidak ya pasti bukan kelompoknya. Tetapi kalau klaster tidak harus sama akan tetapi pengelompokannya berdasarkan pada kedekatan dari suatu karakteristik sampel yang ada.

\subsection{Fuzzy C-Means}

Ada beberapa algoritma klastering data, salah satu diantaranya adalah Fuzzy C-Means (FCM). Fuzzy C-Means (FCM) adalah suatu teknik pengklasteran data yang mana keberadaan tiap-tiap titik data dalam suatu klaster ditentukan oleh derajat keanggotaan. Teknik ini pertama kali diperkenalkan oleh Jim Bezdek pada tahun 1981. Fuzzy C-Means memungkinkan pengelompokkan dimana kelompok data tidak terdistribusi secara jelas.

Fuzzy berarti sesuatu yang bersifat kabur dan tidak jelas, dimana logika fuzzy itu sendiri berarti mengalokasikan nilai kebenaran dari sebuah variabel ke dalam rentang nilai 0 dan 1 agar berbeda dengan logika tradisonal yang mengalokasikan nilai kebenaran tepat pada nilai 0 atau 1 . C disini berarti banyaknya konstanta klaster yang diinginkan, oleh sebab itu pada algoritma ini banyaknya jumlah klaster yang ingin digunakan harus ditentukan di awal. Means diartikan sebagai nilai rerata dalam suatu kelompok data, dalam hal ini didefiniskan sebgai klaster. Secara harafiah jika ketiganya digabungkan maka dapat diartikan bahwa algoritma ini mengghitung nilai rerata.

Konsep dasar Fuzzy C-Means (FCM), pertama kali adalah menentukan pusat klaster, yang akan menandai lokasi rata-rata untuk tiap-tiap klaster. Pada lokasi awal, pusat klaster ini masih belum akurat. Tiaptiap titik data memiliki derajat keanggotaan untuk tiap-tiap klaster. Dengan cara memperbaiki pusat klaster dan derajat keanggotaan tiap-tiap titik data secara berulang, maka akan dapat dilihat bahwa pusat klaster akan 
bergerak menuju lokasi yang tepat. Perulangan ini didasarkan pada minimisasi fungsi obyektif yang menggambarkan jarak dari titik data yang diberikan ke pusat klaster yang terbobot oleh derajat keanggotaan titik data tersebut.

\subsection{Algoritma Fuzzy C-Means}

Algoritma Fuzzy C-Means (FCM) adalah sebagai berikut.

a. Input data yang akan diklaster $X$, berupa matriks berukuran $n \times m(n=$ jumlah sampel data, $m=$ atribut setiap data). $X_{i j}=$ data sampel ke- $i$, atribut ke- $j$.

$$
\left[\begin{array}{cccc}
x_{11} & x_{12} & \ldots & x_{1 m} \\
x_{21} & x_{22} & \ldots & x_{2 m} \\
\vdots & \vdots & & \vdots \\
x_{n 1} & x_{n 2} & \ldots & x_{n m}
\end{array}\right]
$$

b. Tentukan:

1) Jumlah klaster $=c$

2) Pangkat $=w$

3) Maksimum iterasi = Maxiter

4) Error terkecil yang diharapkan $=\xi$

5) Fungsi objektif awal $\quad=P_{0}=0$

6) Iterasi awal $=t=1$.

c. Bangkitkan bilangan random $\mu_{i k}, i=1,2, \cdots, n ; k=1,2, \cdots, c$; sebagai elemen-elemen matriks partisi awal $U$. Dengan nilai $\mu_{i k}$ diantara 0 dan 1 dan jumlah setiap barisnya sama dengan 1 .

Hitung jumlah setiap kolom:

$$
Q_{i}=\sum_{k=1}^{c} \mu_{i k}
$$

dengan $j=1,2, \cdots, n$.

Hitung : $\mu_{i k}=\frac{\mu_{i k}}{Q_{i}}$

d. Hitung pusat klaster ke- $k$ : $V_{k j}$, dengan $k=1,2, \ldots, c$; dan $j=1,2, \ldots, m$.

$$
V_{k j}=\frac{\sum_{i=1}^{n}\left(\left(\mu_{i k}\right)^{w} * X_{i j}\right)}{\sum_{i=1}^{n}\left(\mu_{i k}\right)^{w}}
$$

e. Hitung fungsi objektif pada iterasi ke-t, Pt.

$$
P_{t}=\sum_{i=1}^{n} \sum_{k=1}^{c}\left(\left[\sum_{j=1}^{m}\left(X_{i j}-V_{k j}\right)^{2}\right]\left(\mu_{i k}\right)^{w}\right)
$$

f. Hitung perubahan matriks partisi:

$$
\mu_{i k}=\frac{\left[\sum_{j=1}^{m}\left(X_{i j}-V_{k j}\right)^{2}\right]^{\frac{-1}{w-1}}}{\sum_{k=1}^{c}\left[\sum_{j=1}^{m}\left(X_{i j}-V_{k j}\right)^{2}\right]^{\frac{-1}{w-1}}}
$$

dengan $i=1,2, \ldots, n$ dan $k=1,2, \ldots, c$.

g. Cek kondisi berhenti:

1) Jika $(|P t-(P t-1)|<\xi)$ atau ( $>$ MaxIter) maka berhenti;

2) Jika tidak $: t=t+1$, ulangi langkah ke-4 (langkah d). 


\subsection{Kelayakan Rumah}

Rumah adalah tempat untuk tumbuh dan berkembang, baik secara jasmani, rohani dan sosial. Definisi ini membawa banyak konsekuensi yakni bahwa selain kualitas rumah yang harus baik, diperlukan pula segala fasilitas yang dibutuhkan untuk tumbuh dan berkembang. Fasilitas itu misalnya fasilitas pendidikan, pasar/toko, tempat kerja, fasilitas air bersih dan sanitasi.

Berdasarkan Undang-Undang No. 4 Tahun 1992 tentang Perumahan dan Permukiman [4], disebutkan bahwa permukiman adalah bagian dari lingkungan hidup diluar kawasan hutan lindung, baik yang berupa kawasan perkotaan maupun pedesaan yang berfungsi sebagai lingkungan tempat tinggal atau lingkungan hunian dan tempat kegiatan yang mendukung perikehidupan dan penghidupan. Dan berdasarkan Peraturan Pemerintah No. 80 tahun 1999 tentang kawasan siap bangun dan lingkungan siap bangun berdiri sendiri [5], rumah layak huni adalah rumah yang memenuhi persyaratan kesehatan, keselamatan dan kenyamanan. Menurut Johan Silas, rumah disebut layak bila memenuhi aspek sehat, aman, terjamin, dapat dicapai dan mampu dibayar, termasuk kebutuhan dasar, bebas dikriminasi dan kepastian kepemilikannya. Rumah akan menjadi tempat tinggal yang aman dan nyaman, bila memiliki kualitas bangunan yang baik, lengkap dengan fasilitasnya, serta berada dalam lingkungan yang bersih dan sehat. Semakin baik kondisi dan kualitas rumah yang ditempati menunjukkan semakin baik keadaan sosial ekonomi rumah tangga.

Secara umum rumah dapat dikatakan layak huni apabila memiliki jenis lantai, dinding dan atap yang memenuhi syarat atau memiliki kualitas yang baik, serta mempunyai luas lantai yang mencukupi. Selain itu, rumah layak huni juga ditentukan oleh fasilitas penerangan, air minum, dan tempat pembuangan akhir kotoran/tinja.

Belum ada kriteria khusus untuk menentukan rumah dikatakan layak, namun menurut Kementrian Pekerjaan Umum dan Perumahan Rakyat, definisi rumah tidak layak huni adalah sebagai berikut:

1. Bahan lantai berupa tanah atau kayu kelas IV

2. Bahan dinding berupa bilik bambu/kayu/rotan atau kayu kelas IV

3. Bahan atap berupa daun atau genteng plentong yang sudah rapuh

4. Rusak berat, dan/atau

5. Rusak sedang dan luas bangunan tidak mencukupi standar minimal luas per anggota keluarga yaitu $9 \mathrm{~m}^{2}$

Pada penelitian ini, yang akan menjadi kriteria penilaian rumah hunian yang layak yaitu ukuran rumah, jenis lantai, jenis dinding, jenis atap, kepemilikan rumah, sumber air minum, sumber penerangan dan keberadaan jamban.

Berdasarkan [6], untuk menentukan kelayakan digunakan persamaan:

$$
\text { Kelayakan }=\left(\frac{\left(\frac{\sum \text { nilai yang mendekati layak }}{\sum \text { nilai per cluster }}\right) \times 100 \%}{\sum \text { kriteria }}\right) \text {. }
$$

\subsection{Validitas Fuzzy C-Means}

Bezdek [1] mengusulkan validitas dengan menghitung koefisien partisi atau partition coefficient (PC) sebagai evaluasi nilai keanggotaan data pada setiap klaster. Nilai PC Index (PCI) hanya mengevaluasi nilai derajat keanggotaan, tanpa memandang nilai vektor (data) yang biasanya mengandung informasi geometrik (sebaran data). Nilainya dalam rentang [0,1], nilai yang semakin besar (mendekati 1) mempunyai arti bahwa kualitas klaster yang didapat semakin baik. Berikut formula untuk menghitung PC Index:

$$
P C I=\frac{1}{N}\left(\sum_{i=1}^{N} \sum_{j=1}^{K} u_{i j}^{2}\right),
$$

dimana $N$ merupakan jumlah data dalam set data, $K$ merupakan jumlah klaster, sedangkan $u_{i j}$ menyatakan nilai keanggotaan data ke-i pada klaster ke-j.

Bezdek [7] sebelumnya telah mengusulkan validitas dengan menghitung entropi partisi atau partition entropy (PE). Nilai PE Index (PEI) mengevaluasi keteracakan data dalam klaster. Nilainya dalam rentang [0,1], 
nilai yang smakin kecil (mendekati 0) mempunyai arti bahwa kualitas klaster yang didapat semakin baik. Berikut formula untuk menghitung PE Index:

$$
P E I=-\frac{1}{N}\left(\sum_{i=1}^{N} \sum_{j=1}^{K} u_{i j} x \log _{2} u_{i j}\right)
$$

Kedua metrik PCI dan PEI memiliki kecenderungan monotonik terhadap K. Modifikasi nilai PCI (MPCI) dilakukan oleh Dave (1996) terhadap kecenderungan monotonik tersebut. Formula yang digunakan seperti berikut:

$$
M P C I=1-\frac{K}{K-1}(1-P C I) .
$$
(NFI).

Nilai MPCI yang didapat adalah $0 \leq M P C I \leq 1$. Nilai MPCI ekuivalen dengan Non-Fuzziness Index

Fukuyama dan Sugeno [8] mengusulkan validitas dengan formula seperti pada persamaan berikut:

$$
F S I=\sum_{j=1}^{N} \sum_{i=1}^{K} u_{i j}^{m} x d\left(x_{i}, c_{j}\right)^{2}-\sum_{j=1}^{N} \sum_{i=1}^{K} u_{i j}^{m} x d\left(c_{j}, \bar{x}\right)^{2}=J_{m}(u, c)-K_{m}(u, c) ;
$$

dimana $m$ merupakan bobot pangkat (weighting exponent), nilainya $m>1$. $d\left(x_{i}, c_{j}\right)$ merupakan jarak antara data ke-i terhadap centroid klaster ke-j. $C_{j}$ adalah centroid klaster ke-j. $d\left(c_{j}, \bar{x}\right)$ merupakan jarak antara centroid hasil klastering terhadap rata-rata semua data. $J_{m}(u, c)$ adalah nilai fungsi obyektif yang mengukur kohesi, sedangkan $K_{m}(u, c)$ adalah nilai obyektif yang mengukur nilai separasi. Secara umum nilai Fukuyama Sugeno Index (FSI) yang semakin kecil mempunyai arti bahwa kualitas klaster yang didapat semakin baik [9].

Validitas untuk mengevaluasi klaster yang dimodifikasi oleh Pal dan Bezdek [10] diberikan oleh formula berikut:

$$
X B I=\frac{\sum_{j=1}^{K} \sum_{i=1}^{K} u_{i j}^{m} x d\left(x_{i}, c_{j}\right)^{2}}{N x \min _{i, j}\left(d\left(c_{i}, c_{j}\right)^{2}\right)}=\frac{\frac{J_{m}(u, c)}{N}}{\operatorname{Sep}(c)}
$$

$J_{m}(u, c)$ adalah ukuran kohesi, sedangkan Sep (c) adalah ukuran separasi.

Secara umum, nilai yang terbaik untuk Xie Beni Index (XBI) adalah nilai index yang semakin kecil. Nilai XBI yang semakin kecil mempunyai arti kualitas hasil pngelompokkan yang semakin baik [9].

Wu dan Yang [9] mengusulkan cara mengevaluasi klaster dengan menghitung Partition Coefficient and Exponential Separation (PCAES) Index. PCAES Index (PCAESI) untuk klaster ke-i didefinisikan sebagai gabungan antara kohesi dan separasi klaster tersebut. Ukuran kohesi klaster ke-j relatif terhadap kohesi keseluruhan klaster diukur terhadap $u_{M}$, seperti pada persamaan berikut:

$$
K_{o h}=\sum_{i=1}^{N} \frac{u_{i j}^{2}}{u_{M}}
$$

Sementara $u_{M}$ didapatkan dari persamaan berikut:

$$
u_{M}=\min _{1 \leq j \leq K}\left\{\sum_{i=1}^{N} u_{i j}^{2}\right\}
$$

Separasi klaster ke-j terhadap klaster lain yang terdekat relatif terhadap separasi semua klaster diukur terhadap $\beta_{T}$, seperti pada persamaan berikut:

$$
\operatorname{Sep}_{j}=\exp \left(\frac{\min _{k \neq j}\left\{d\left(c_{j}, c_{k}\right)^{2}\right\}}{\beta_{T}}\right), \text { untuk } k=1, \ldots, K
$$


Untuk $\beta_{T}$ dinyatakan oleh persamaan berikut:

$$
\beta_{T}=\frac{1}{K} \sum_{j=1}^{K} d\left(c_{j}, \bar{x}\right)^{2}
$$

Untuk menghitung PCAESI pada klaster ke-j dirumuskan sebagai berikut:

$$
\text { PCAESI }_{j}=\mathrm{Koh}_{j}-\mathrm{Sep}_{j} .
$$

Nilai PCAESI $j$ yang besar berarti klaster ke-j bersifat kohesif (kompak) didalam dan terpisah dari (K-1) klaster yang lain. Nilai yang kecil atau negatif menunjukkan bahwa klaster ke-j dikenali sebagai klaster yang kurang baik [9].

Nilai kohesi total semua klaster didapatkan dengan menjumlahkan semua nilai kohesi dari setiap klaster, seperti pada persamaan berikut:

$$
K o h=\sum_{j=1}^{K} K o h_{j}
$$

Sementara separasi total semua klaster didapatkan dengan menjumlahkan semua nilai separasi dari setiap klaster seperti pada persamaan berikut:

$$
\text { Sep }=\sum_{j=1}^{K} \operatorname{Sep}_{j}
$$

Validias total dalam PCAES Index didefinisikan oleh persamaan berikut:

$$
\text { PCAESI }=\sum_{j=1}^{K} \text { PCAESI }_{j}=K o h-S e p=\sum_{j=1}^{K} K o h_{j}-\sum_{j=1}^{K} \operatorname{Sep}_{j}
$$

Nilai PCAESI yang besar berarti K klaster bersifat kohesif (kompak) dan terpisah satu sama lain. Nilai PCAESI yang kecil berarti ada beberapa K klaster yang tidak kompak atau terpisah dari yang lain. Nilai maksimal PCAESI, yaitu K, dapat digunakan untuk mendeteksi struktur klaster data dengan partisi kompak dan terpisah dengan baik [9].

\section{Metode Penelitian}

Penelitian ini menggunakan studi kasus yaitu dengan menerapkan metode pengklasteran dengan Algoritma Fuzzy C-Means berdasarkan kriteria-kriteria yang mempengaruhi kelayakan rumah hunian. Pada penelitian ini yang dijadikan unit observasi adalah Desa Wayame, Kota Ambon.

Data yang digunakan dalam penelitian ini adalah data primer yang diambil secara random dari rumah masyarakat setempat. Dalam penelitian ini variabel yang digunakan untuk penentuan kelayakan rumah hunian menggunakan algoritma Fuzzy C-Means adalah sebagai berikut:
a. $\mathrm{X}_{1}$ : Atap rumah
b. $X_{2}$ : Dinding rumah
c. $\mathrm{X}_{3}$ : Lantai rumah
d. $\mathrm{X}_{4}$ : Keberaadaan jamban
e. $\mathrm{X}_{5}$ : Kepemilikan rumah
f. $\mathrm{X}_{6}$ : Ukuran rumah
g. $\mathrm{X}_{7}$ : Sumber air minum
h. $\mathrm{X}_{8}$ : Sumber penerangan 


\section{Prosedur Penelitian}

Prosedur yang dilakukan dalam penelitian ini berkaitan dengan tujuan penelitian adalah menentukan kelayakan rumah hunian berdasarkan kriteria-kriteria yang telah ditetapkan dengan langkah-langkah sebagai berikut:

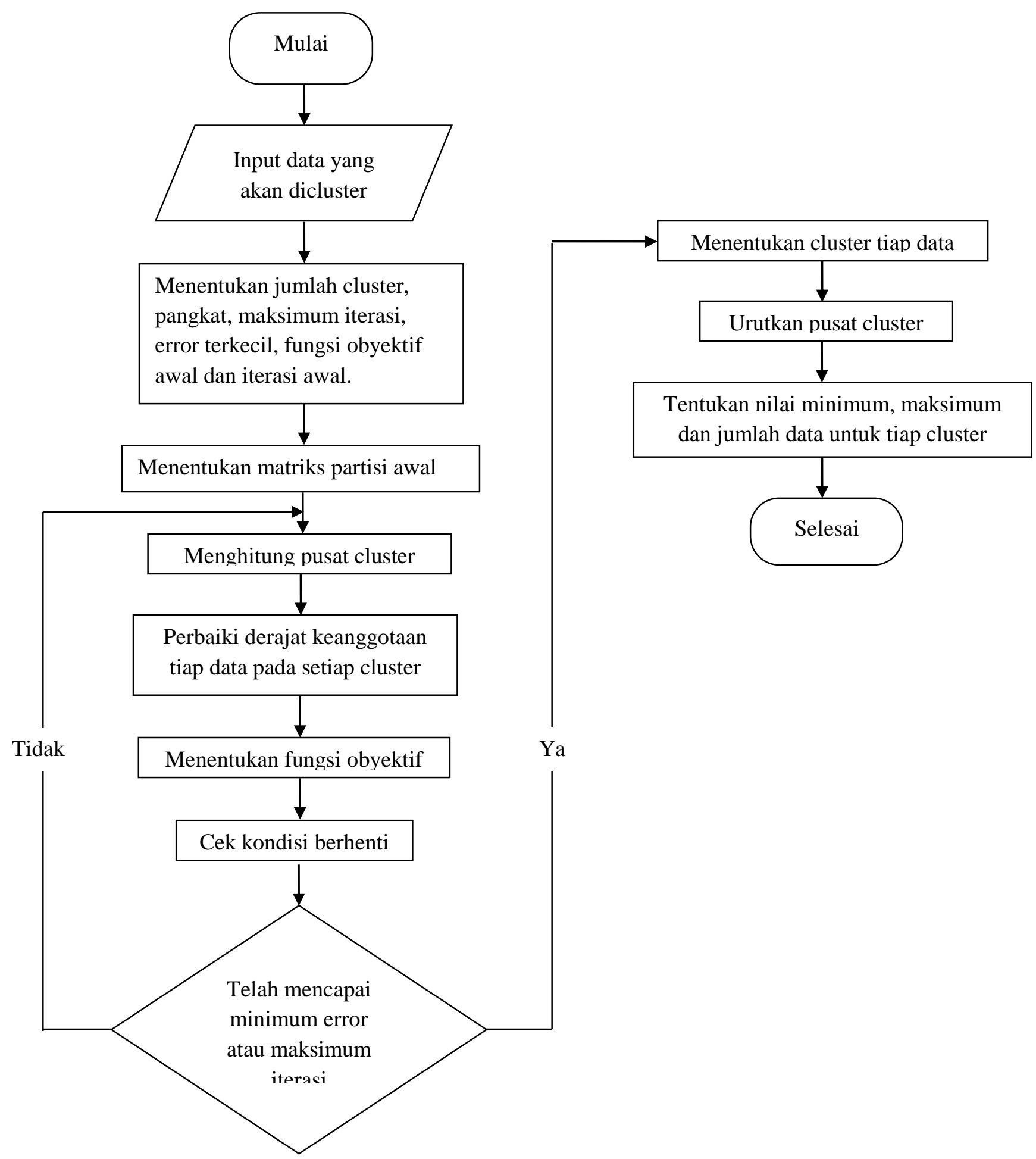

Gambar 1. Diagram Alur Algoritma Fuzzy C-Means 


\section{Hasil dan Pembahasan}

Bagian ini memuat tentang analisis data dan hasil pengklasteran menggunakan metode Fuzzy C-Means dengan menggunakan software MATLAB. Data yang digunakan dalam penelitian ini, diambil secara random pada masyarakat di Desa Wayame (dua dusun yaitu dusun Keranjang dan Dusun Waringin Cap). Untuk menentukan kelayakan rumah, prosesnya dimulai dari pengumpulan data rumah yang didasarkan atas kriteriakriteria penilaian rumah. Kriteria-kriteria yang digunakan untuk melakukan penilaian tersebut adalah:

a. Jenis Atap

Jenis atap terluas yang digunakan pada rumah tersebut dibagi atas tiga kategori yaitu: Daun/rumbia (1), Seng/abses (2), dan genteng (3).

b. Jenis dinding

Jenis dinding dibagi atas tiga kategori yaitu: Tidak permanen (1), semi permanen (2) dan permanen (3).

c. Jenis Lantai

Jenis lantai dibagi atas tiga kategori yaitu: Lantai masih tanah (1), lantai menggunakan semen atau papan

(2) dan lantai menggunakan ubin (3).

d. Keberadaan Jamban

Keberadaan pada tiap rumah huni dibagi atas tiga kategori yaitu: jamban umum (1), jamban bersama (2) dan jamban sendiri (3).

e. Status Kepemilikan rumah

Status kepemilikan rumah dibagi atas dua kategori yaitu: bukan pemilik (1) dan pemilik (2).

f. Luas bangunan rumah

Luas bangunan rumah $\left(\mathrm{m}^{2}\right)$ tidak dikategorikan.

g. Sumber air minum

Sumber air minum dibagi atas 3 kategori yaitu air hujan/air sungai (1), sumur/pompa (2), dan ledeng/kemasan (3).

h. Sumber penerangan

Sumber penerangan dibagi atas 3 kategori yaitu lampu minyak (1), genset/disel (2), dan listrik (3).

Berdasarkan hasil pengumpulan data dari 8 kriteria di atas, ternyata hanya 5 kriteria yang berpengaruh dalam proses pengklasteran. Kelima kriteria tersebut yaitu jenis atap, jenis dinding, jenis lantai, keberadaan jamban dan luas bangunan rumah. Dengan demikian, kriteria sumber penerangan, sumber air minum dan kepemilikan rumah tidak berpengaruh karena hasil yang diperoleh saat menggunakan 8 kriteria di atas sama dengan hasil yang diperoleh menggunakan 5 kriteria (jenis atap, jenis dinding, jenis lantai, keberadaan jamban dan luas bangunan rumah). Hal ini dapat terjadi karena semua observasi memiliki kesamaan dalam 3 kriteria tersebut (sumber penerangan, sumber air minum dan kepemilikan rumah).

Langkah awal dari proses pengklasteran ini adalah menentukan parameter awal yang akan digunakan untuk menyelesaikan masalah dengan algoritma Fuzzy C-means. Parameter-parameter tersebut adalah
a. Jumlah klaster (c)
$=2$
b. Pangkat (w)
$=2$
c. Maksimum iterasi (MaxIter)
$=100$
d. Error terkecil yang diharapkan $(\xi) \quad=10^{-5}$
e. Fungsi objektif awal $\left(\mathrm{P}_{0}\right)$
$=0$

Beberapa hal penting yang diperoleh dalam proses pengklasteran ini adalah nilai fungsi obyektif selama iterasi, pusat klaster serta derajat keanggotaan rumah setiap klaster pada iterasi terakhir. 
Tabel 1. Nilai obyektif selama 14 iterasi

\begin{tabular}{|c|r|}
\hline Iterasi ke- & Nilai Obyektif \\
\hline 1 & 7440,00566 \\
\hline 2 & 6148,68789 \\
\hline 3 & 4827,08567 \\
\hline 4 & 2986,68849 \\
\hline 5 & 2631,28815 \\
\hline 6 & 2614,98795 \\
\hline 7 & 2614,48678 \\
\hline 8 & 2614,45738 \\
\hline 9 & 2614,45252 \\
\hline 10 & 2614,45142 \\
\hline 11 & 2614,45116 \\
\hline 12 & 2614,45110 \\
\hline 13 & 2614,45109 \\
\hline 14 & 2614,45108 \\
\hline
\end{tabular}

Nilai fungsi obyektif yang diperoleh dalam penelitian ini didasarkan atas proses iterasi. Pada Tabel 1, dapat dilihat bahwa pada iterasi pertama diperoleh nilai fungsi obyektif 7440,00566 . Proses iterasi ini terus berjalan hingga iterasi ke-14 sehingga diperoleh nilai fungsi obyektif adalah 2614,45108 . Proses iterasi berhenti pada iterasi ke-14 dimana nilai $\left|P_{t}-P_{t}-1\right|<\xi$.

Setelah diperoleh nilai fungsi obyektif, maka dapat diperoleh nilai pusat klaster atau centriod yang akan digunakan. Pada iterasi terakhir (iterasi ke-14), diperoleh nilai-nilai pusat klaster yang diberikan dalam bentuk matriks $V_{k j}$. Untuk $k=1,2$ dan $j=1,2,3,4,5$, nilai pusat klaster adalah

$$
V_{k j}=\left(\begin{array}{lllll}
1,9989 & 2,9812 & 2,5257 & 2,9378 & 68,2309 \\
1,8341 & 2,3606 & 2,0676 & 2,3933 & 36,5991
\end{array}\right)
$$

Berdasarkan hasil pengolahan data maka dapat diberikan derajat keanggotaan tiap observasi untuk masing-masing klaster pada iterasi terakhir (iterasi ke-14).

Tabel 2. Derajat Keanggotaan pada Iterasi 14

\begin{tabular}{|c|l|l|}
\hline Observasi ke-i & $\boldsymbol{\mu}_{\mathbf{i} 1}$ & $\boldsymbol{\mu}_{\mathbf{i} 2}$ \\
\hline 1 & 0,0291 & 0,9709 \\
\hline 2 & 0,2414 & 0,7586 \\
\hline 3 & 0,0025 & 0,9975 \\
\hline 4 & 0,5982 & 0,4018 \\
\hline 5 & 0,0293 & 0,9707 \\
\hline 6 & 0,9970 & 0,0030 \\
\hline 7 & 0,9620 & 0,0380 \\
\hline$\vdots$ & $\vdots$ & $\vdots$ \\
\hline 42 & 0,9970 & 0,0030 \\
\hline
\end{tabular}

Dari derajat keanggotaan pada iterasi terakhir tersebut dapat diperoleh informasi mengenai kecenderungan untuk setiap observasi masuk ke klaster mana. Derajat keanggotaan terbesar menunjukkan bahwa kecenderungan tertinggi observasi untuk masuk mejadi anggota klaster tertentu. 
Pada observasi pertama, nilai derajat keanggotaan untuk klaster pertama 0,0291 sedangkan nilai derajat keanggotaan untuk klaster kedua 0,9709. Dari nilai tersebut observasi pertama masuk dalam klaster kedua. Hal itu dikarenakan observasi pertama mempunyai derajat keanggotaan tertinggi di klaster kedua daripada klaster pertama.

Selanjutnya, pada observasi kedua nilai derajat keanggotaan untuk klaster pertama 0,2414 sedangkan nilai derajat keanggotaan untuk klaster kedua 0,7586. Dari nilai tersebut observasi kedua masuk dalam klaster kedua.

Penentuan berlanjut hingga observasi ke-42, dengan nilai derajat keanggotaan untuk klaster pertama 0,9970 sedangkan nilai derajat keanggotaan untuk klaster kedua 0,0030. Dari nilai tersebut observasi ke-42 masuk dalam klaster pertama. Kecenderungan klaster secara keseluruhan dapat dilihat dalam Tabel 3.

Tabel 3. Kecenderungan Klaster

\begin{tabular}{|c|c|c|}
\hline Observasi ke- & Klaster 1 & Klaster 2 \\
\hline 1 & & $*$ \\
\hline 2 & & $*$ \\
\hline 3 & & $*$ \\
\hline 4 & $*$ & \\
\hline 5 & & $*$ \\
\hline 6 & $*$ & \\
\hline 7 & $*$ & \\
\hline 8 & $*$ & \\
\hline 9 & $*$ & \\
\hline 10 & $*$ & \\
\hline 11 & & $*$ \\
\hline 12 & $*$ & \\
\hline 13 & & * \\
\hline 14 & $*$ & \\
\hline 15 & $*$ & \\
\hline 16 & $*$ & \\
\hline 17 & $*$ & \\
\hline 18 & $*$ & \\
\hline 19 & & $*$ \\
\hline 20 & & $*$ \\
\hline 21 & & $*$ \\
\hline
\end{tabular}

\begin{tabular}{|c|c|c|}
\hline Observasi ke- & Klaster 1 & Klaster 2 \\
\hline 22 & $*$ & \\
\hline 23 & $*$ & $*$ \\
\hline 24 & & $*$ \\
\hline 25 & & $*$ \\
\hline 26 & & $*$ \\
\hline 27 & $*$ & $*$ \\
\hline 28 & $*$ & \\
\hline 29 & & $*$ \\
\hline 30 & $*$ & $*$ \\
\hline 31 & & \\
\hline 32 & $*$ & $*$ \\
\hline 33 & $*$ & \\
\hline 34 & & \\
\hline 35 & & $*$ \\
\hline 36 & $*$ & \\
\hline 37 & & \\
\hline 38 & $*$ & \\
\hline 39 & $*$ & \\
\hline 40 & $*$ & \\
\hline 41 & & \\
\hline 42 & $*$ & \\
\hline
\end{tabular}

Setelah didapatkan klaster, maka dilanjutkan dengan memasukkan bobot yang akan menentukan persentase kelayakan, berikut langkah-langkahnya:
1) Jenis atap
2) Jenis dinding
$=2-3$
3) Jenis lantai
$=3$
4) Keberadaan jamban
$=3$
5) Luas rumah
$=3$
$=45 \mathrm{~m}^{2}$

$$
\text { Kelayakan }=\left(\frac{\left(\frac{\text { Enilai yang mendekati layak }}{\text { Enilai per cluster }}\right) \times 100 \%}{\sum \text { kriteria }}\right)
$$

Pada klaster pertama, perhitungan persentase untuk menentukan kelayakan rumah untuk setiap kriteria yaitu: berdasarkan jenis atap $100 \%$, berdasarkan jenis dinding 95,833\%, berdasarkan jenis lantai $54,167 \%$, berdasarkan keberadaan jamban 91,667\%, berdasarkan luas rumah $100 \%$. Rata-rata persentase pada klaster pertama adalah $90,278 \%$. Sehingga persentase kelayakan rumah hunian yang termasuk pada klaster pertama yaitu $90,278 \%$. 
Sedangkan pada klaster kedua, perhitungan persentase untuk menentukan kelayakan rumah untuk setiap kriteria yaitu: berdasarkan jenis atap 83,333\%, berdasarkan jenis dinding 44,444\%, berdasarkan jenis lantai $5,556 \%$, berdasarkan keberadaan jamban 50\%, berdasarkan luas rumah 16,667\%. Rata-rata persentase pada klaster kedua adalah 50\%. Sehingga persentase kelayakan rumah hunian yang termasuk pada klaster kedua yaitu $50 \%$.

Dari hitungan di atas, diambil nilai persentase yang terbesar untuk mendapatkan kelayakan rumah hunian. Sehingga yang termasuk ke dalam kategori layak adalah klaster 1 dengan kelayakan 90\%. Dengan hasil lengkap dari pengklasteran rumah layak dan tidak layak dapat dilihat pada Tabel 4.

Tabel 4. Hasil Pengklasteran

\begin{tabular}{|c|c|}
\hline Klaster & Observasi ke- \\
\hline 1 (kelayakan 90\%) & $4,6,7,8,9,10,12,14,15,16,17,18,22,23,27,28,30,32,33,36,38,39,40,42$ \\
\hline 2 (kelayakan 50\%) & $1,2,3,5,11,13,19,20,21,24,25,26,29,31,34,35,37,41$ \\
\hline
\end{tabular}

Dari tabel di atas dapat dilihat bahwa masih terdapat 18 rumah dengan kelayakan 50\% dari 42 rumah yang menjadi observasi. Dengan persentase rumah yang masuk klaster 1 adalah 57,14\% dan yang masuk klaster 2 adalah 42,86\%. Sehingga masih diperlukannya perhatian khusus untuk melihat kondisi perumahan di daerah tersebut.

\section{Validitas Pengklasteran Menggunakan Fuzzy}

Metode pengelompokkan yang menggunakan konsep fuzzy, sebuah data bisa menjadi anggota di semua klaster dengan nilai derajat keanggotaan yang dimilikinya. Semakin tinggi nilai derajat keanggotaan pada sebuah klaster maka semakin besar kecenderungan menjadi anggota klaster tersebut.

Dari pengolahan data menggunakan Matlab diperoleh hasil validitas Fuzzy seperti pada Tabel 5.

Tabel 5. Validitas dengan Jarak Euclidean dan City Block

\begin{tabular}{|l|l|l|}
\hline Jarak & Eucledian & City Block \\
\hline PCI & 0,8614 & 0,8614 \\
\hline PEI & 0,3408 & 0,3408 \\
\hline MPCI & 0,7229 & 0,7229 \\
\hline FSI & $-6,3955 \mathrm{e}+003$ & $-6,8651 \mathrm{e}+003$ \\
\hline XBI & 0,0622 & 0,0679 \\
\hline PCAESI & 1,1452 dan 0,9810 & 1,1452 dan 0,9810 \\
\hline PCAESI total & 2,1262 & 2,1262 \\
\hline
\end{tabular}

Dari hasil validasi, dapat dilihat bahwa nilai yang didapat dengan kedua jarak yang digunakan hampir sama. Dengan penjelasan:

- Nilai PCI (partition coefficient index) yaitu 0,8614 (mendekati 1) sama pada kedua jarak mempunyai arti bahwa kualitas klaster yang didapat baik.

- Nilai PEI (partition entrophy index) yaitu 0,3408 (mendekati 0) sama pada kedua jarak mempunyai arti bahwa kualitas klaster yang didapat baik.

- Nilai MPCI yaitu 0,7229 (mendekati 1) sama pada kedua jarak yang digunakan mempunyai arti bahwa kualitas klaster yang didapat baik

- Nilai FSI hampi sama pada kedua jarak yaitu -6,3955e+003 untuk Euclidean dan -6,8651e+003 untuk City Block, mempunyai arti bahwa kualitas klaster yang didapat baik.

- Nilai XBI yaitu 0,0622 untuk Euclidean dan 0,0679 untuk City Block, mempunyai arti bahwa kualitas hasil pengelompokan baik. 
- Nilai PCAESI untuk klaster ke 1 dan klaster ke 2 yaitu 1,1452 dan 0,9810, karena nilainya cukup besar dan tidak negatif maka berarti masing-masing klaster bersifat kohesif (kompak) di dalam dan terpisah dari klaster yang lain.

- Nilai PCAESI total yaitu 2,1262 untuk kedua jarak yang digunakan, mempunyai arti bahwa klaster bersifat kohesif (kompak) dan terpisah dari klaster yang lain.

Sehingga dapat disimpulkan bahwa 2 klaster baik untuk digunakan pada pengelompokan data untuk menentukan kelayakan rumah.

\section{Kesimpulan}

Algoritma Fuzzy C-Means merupakan salah satu teknik pengklasteran data yang mana keberadaan tiaptiap titik data dalam suatu klaster ditentukan oleh derajat keanggotaannya. Dalam penelitian ini dilakukan pengklasteran terhadap 42 sampel rumah dari dua dusun di desa Wayame. Berdasarkan pengklasteran yang dilakukan diperoleh 2 klaster. Dari kedua klaster tersebut diketahui bahwa klaster pertama merupakan klaster yang beranggotakan rumah yang tidak layak yaitu 18 rumah terdiri atas 9 rumah pada Dusun Keranjang dan 9 rumah pada Dusun Waringin Cap, sedangkan klaster kedua merupakan klaster yang beranggotakan rumah yang layak yaitu 24 rumah terdiri atas 13 rumah pada dusun Keranjang dan 11 rumah pada Dusun Waringin Cap.

\section{Daftar Pustaka}

[1] J. C. Bezdek, Pattern Recognition with Fuzzy Objective Function Algorithms, New York: Plenum, 1981.

[2] M. Mirza and Faisal, "Metode Klastering dengan Algoritma Fuzzy C-Means untuk Rekomendasi Pemilihan Bidang Keahlian Pada Program Studi Teknik Informatika," 2013.

[3] U. Fadilah, "Analisis Penyandang Masalah Kesejahteraan Sosial di Indonesia Menggunakan Metode Fuzzy CMeans Klastering dan Biplot," 2011.

[4] Undang-Undang Nomor 4 Tahun 1992 Tentang Perumahan dan Permukiman.

[5] Peraturan Pemerintah No. 80 tahun 1999 Tentang Kawasan Siap Bangun dan Lingkungan Siap Bangun Berdiri Sendiri.

[6] R. Putra, N. Nasution and Yummastian, "Aplikasi E-Zakat dan Penyaluran Menggunakan Fuzzy C-Means (Studi Kasus: LAZISMU Pekanbaru),” 2015.

[7] J. C. Bezdek, "Cluster Validity with Fuzzy Set,” J. Cybernet, vol. 3, no. 3, pp. 58-72, 1974.

[8] Y. Fukuyama and M. Sugeno, "A New Method Measurements in Taxonomic Problems," Annals of Eugenics, vol. 7, no. 11, pp. 179-188, 1989.

[9] K. L. Wu and M. S. Yang, "A Cluster Validity Index for Fuzzy Clustering," Pattern Recognition Letters, vol. 26, pp. 1275-1291, 2005.

[10] N. R. Pal and J. C. Bezdek, "On Cluster Validity for Fuzzy C-Means Model," IEEE Transactions of Fuzzy Systems, vol. 3, no. 3, pp. 370-379, 1995. 